\title{
Pengaruh Langsung dan Tidak Langsung Dana Perimbangan Melalui Belanja Modal terhadap Pertumbuhan Ekonomi di Provinsi Jambi
}

\author{
Evi Adriani" ${ }^{* 1}$ Ali Fahmi ${ }^{2}$, Muhammad Syukri ${ }^{3}$ \\ ${ }^{1,3}$ Fakultas Ekonomi Universitas Batanghari \\ ${ }^{2}$ Fakultas Ekonomi dan Bisnis Universitas Muhammadiyah Jambi \\ Corresponding email: adrianievifahlevi@gmail.com
}

\begin{abstract}
This study aims to find out: (1) The direct effect of balance funds on economic growth. (2) The indirect effect of balance funds through capital expenditures on economic growth. This study used secondary data in the form of panel data during the years 2014-2019 of districs/cities in Jambi Province. The data was obtained from the Central Statistics Agency (BPS) and the Directorate General of Financial Balance (DJPK). Path Analysis model with Linear Regression Analysis approach is gradually used to analyze the direct and indirect effect between exogenous and endogenous variables in the presence of intervening variables. The results showed that: (1) The balance fund directly had a significant effect on economic growth. (2) The balance funds indirectly through capital expenditures has no significant effect on economic growth. Based on the results, it was hope that provides benefits for local government to utilize effectively and efficiently the regional revenues and as input for further research to getting even better results.
\end{abstract}

Keywords: Balance Fund, Capital Expenditures, Economic Growth, Path Analysis

\section{Pendahuluan}

Dalam era otonomi daerah, daerah diberikan kewenangan untuk mengurus rumah tangganya sendiri dengan tujuan untuk lebih mendekatkan pelayanan pemerintah kepada masyarakat, memudahkan masyarakat untuk memantau dan mengontrol penggunaan dana yang bersumber dari Anggaran Pendapatan dan Belanja Daerah (APBD) (Amin, 2019). Dalam rangka pelaksanaan otonomi daerah diharapkan masing-masing daerah dapat mandiri dalam hal pengelolaan keuangan daerah untuk membiayai kegiatan pembangunan daerah. Pelaksanaan pembangunan daerah ini dimaksudkan untuk meningkatkan pertumbuhan ekonomi daerah dan meningkatkan kesejahteraan masyarakat. Terlaksananya pembangunan dan pertumbuhan ekonomi daerah dipengaruhi oleh bagaimana cara pemerintah daerah dalam memanfaatkan keuangan daerah. Pengelolaan keuangan daerah ini tercermin dalam Anggaran Pendapatan dan Belanja Daerah. APBD merupakan gambaran kemampuan daerah dalam membiayai kegiatan pembangunan. Dalam proses pembiayaan kegiatan pembangunan ini dibutuhkan salah satu intrumen dalam APBD yaitu berupa belanja daerah, dan salah satu bagian dari belanja daerah yang digunakan dalam membiayai kegiatan pembangunan yaitu berasal dari belanja modal. Alokasi belanja modal didasarkan pada kebutuhan daerah akan sarana dan prasarana yang dapat berupa belanja modal tanah, gedung dan bangunan, mesin, infrastruktur dan belanja modal lainnya, baik untuk kelancaran pelaksanaan tugas pemerintahan dan fasilitas publik.

Dalam menentukan alokasi belanja modal dipengaruhi oleh penerimaan daerah yang bersangkutan. Penerimaan daerah dapat bersumber dari Pendapatan Asli Daerah (PAD) dan dana transfer dari pemerintah pusat dalam bentuk Dana Perimbangan. Dalam proses pembangunan disuatu daerah, dana yang dibutuhkan untuk membiayai kegiatan pembangunan tidak hanya cukup dengan PAD saja, karena porsi dari PAD belum mampu mencukupi kebutuhan daerah. Sehingga pemerintah pusat mengalokasikan dana perimbangan yang bersumber dari Anggaran Pendapatan dan Belanja Negara kepada pemerintah daerah untuk mendanai kebutuhan daerah dalam pelaksanaan desentralisasi dan untuk memajukan pembangunan di setiap daerah. Dana perimbangan merupakan sumber pendanaan bagi daerah dalam pelaksanaan pembangunan dalam hal ini di bidang infrastruktur. Oleh karena itu, semakin besar/kecilnya penerimaan dana perimbangan yang diterima oleh daerah, maka dapat mempengaruhi besar/kecilnya alokasi belanja modal yang dikeluarkan oleh daerah untuk membiayai kegiatan pembangunan daerah. Provinsi Jambi merupakan salah satu daerah di Indonesia yang terdiri dari 9 (Sembilan) Kabupaten dan 2 (dua) Kota berupaya meningkatkan pertumbuhan ekonomi dalam melaksanakan pembangunan untuk meningkatkan kesejahteraan bagi masyarakat. Laju pertumbuhan ekonomi di Kabupaten/Kota di Provinsi Jambi dalam periode 2014-2019 mengalami perkembangan yang berfluktuatif. Kabupaten/Kota di Provinsi Jambi yang mengalami rata-rata perkembangan laju pertumbuhan ekonomi terendah yaitu terjadi di Kabupaten Sarolangun yaitu sebesar 4.51\%, sedangkan Kabupaten/Kota yang mengalami rata-rata perkembangan laju pertumbuhan ekonomi tertinggi terjadi di Kabupaten Kerinci yaitu sebesar 6.39\%. 
Evi Adriani et al., Pengaruh Langsung dan Tidak Langsung Dana Perimbangan Melalui Belanja Modal terhadap Pertumbuhan Ekonomi di Provinsi Jambi

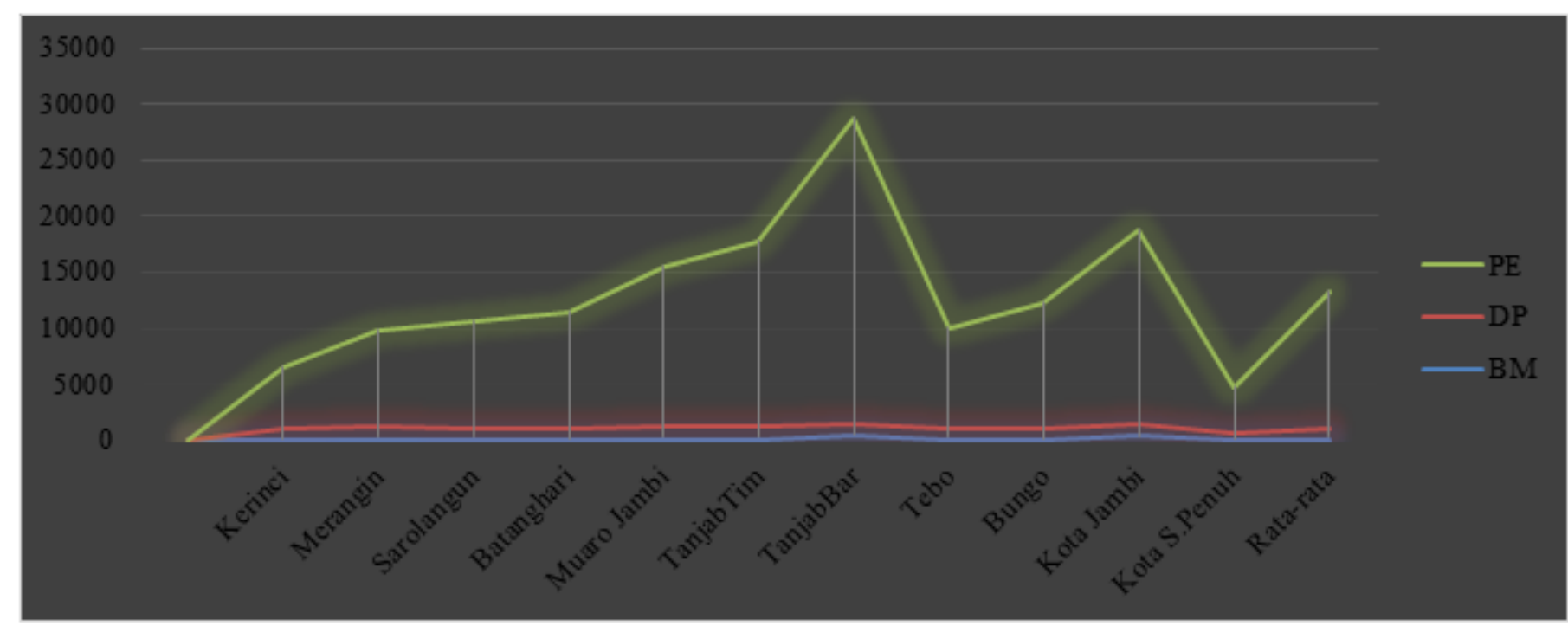

Sumber: Data Olahan

\section{Perkembangan Dana Perimbangan, Belanja Modal dan PDRB Kabupaten/Kota Provinsi Jambi Tahun 2014-2019}

Dalam meningkatkan porsi belanja modal yang akan digunakan dalam pelaksanaan pembangunan daerah, Provinsi Jambi berupaya untuk meningkatkan pendapatan daerah. Pendapatan daerah dapat bersumber dari Pendapatan Asli Daerah (PAD) dan Dana Perimbangan. Proporsi Dana Perimbangan dalam membiayai kegiatan pembangunan di provinsi Jambi lebih besar dibanding PAD, seperti terlihat pada Gambar 1. Kabupaten/Kota yang mengalami rata-rata perkembangan dana perimbangan terendah terjadi di Kota Sungai Penuh yaitu sebesar Rp. 541,337 miliar, sedangkan Kabupaten/Kota yang mengalami rata-rata perkembangan dana perimbangan terbesar terjadi di Kota Jambi yaitu sebesar Rp. 1,020,484 miliar. Gambar 1, dapat dilihat bahwa arah perkembangan Dana Perimbangan dan Belanja Modal pada kabupaten/kota di provinsi Jambi tidak selalu seperti yang seharusnya, begitu juga jika dihubungkan dengan pertumbuhan ekonomi yang dalam hal ini digambarkan dengan PDRB atas harga konstan. Dapat dilhat bahwa adanya kenaikan pada pengeluaran belanja modal tidak diikuti dengan peningkatan pada laju pertumbuhan ekonomi pada Kabupaten/Kota di Provinsi Jambi. Demikian juga realisasi kenaikan dana perimbangan tidak selalu diikuti dengan peningkatan pada belanja modal Kabupaten/Kota di Provinsi Jambi selama periode 2014-2019, dan sebaliknya. Tujuan dalam penelitian ini adalah: 1) Mengetahui pengaruh langsung Dana Perimbangan terhadap Pertumbuhan Ekonomi pada Kabupaten/Kota di Provinsi Jambi tahun 2014-2019; dan 2) Mengetahui pengaruh tidak langsung Dana Perimbangan melalui Belanja Modal terhadap Pertumbuhan Ekonomi pada Kabupaten/Kota di Provinsi Jambi tahun 2014-2019.

\section{Pertumbuhan Ekonomi}

Pertumbuhan ekonomi adalah perkembangan kegiatan dalam perekonomian yang menyebabkan barang dan jasa yang diproduksi dalam masyarakat bertambah (Sukirno, 2012). Pertumbuhan ekonomi menunjukkan sejauh mana aktivitas perekonomian akan menghasilkan tambahan pendapatan masyarakat pada suatu periode tertentu. Pertumbuhan ekonomi merupakan salah satu indikator utama dalam proses pembangunan di suatu negara. Besar kecilnya pertumbuhan ekonomi mencerminkan kemampuan negara dalam mengelola sumber daya ekonominya untuk menghasilkan output perekonomiannya (Frisdiantara, 2018).

\section{Belanja Modal}

Belanja modal merupakan pengeluaran untuk pembayaran perolehan asset tetap dan/atau asset lainnya atau menambah nilai asset tetap dan/atau asset lainnya yang memberi manfaat lebih dari satu periode akuntansi dan melebihi batas minimal kapitalisasi asset tetap/asset lainnya yang ditetapkan pemerintah (Peraturan Menteri Keuangan Nomor 134/PMK.02/2012). Belanja modal dipergunakan untuk belanja modal tanah, peralatan dan mesin, gedung dan bangunan, jalan irigasi dan jaringan, badan layanan umum dan belanja modal lainnya.

\section{Dana Perimbangan}

Dana Perimbangan adalah dana yang bersumber dari pendapatan APBN yang dialokasikan kepada Daerah untuk mendanai kebutuhan Daerah dalam rangka pelaksanaan Desentralisasi. Dana perimbangan terdiri dari dana bagi hasil, dana alokasi umum dan dana alokasi khusus. 


\section{Pengaruh Dana Perimbangan Terhadap Belanja Modal Serta Dampaknya Terhadap Pertumbuhan Ekonomi}

Dana perimbangan merupakan dana yang diberikan oleh pemerintah pusat yang bersumber dari APBN. Alokasi dana perimbangan bertujuan untuk pemerataan kemampuan keuangan antar daerah untuk membiayai kebutuhan daerah dalam rangka pelaksanaan desentralisasi. Dana perimbangan merupakan sumber pendanaan bagi daerah dalam pelaksanaan pembangunan dalam hal ini di bidang infrastruktur. Oleh karena itu, semakin besar/kecilnya dana perimbangan yang diperoleh daerah, maka dapat mempengaruhi besar/kecilnya alokasi belanja modal daerah tersebut. Dengan tersedianya infrastruktur yang baik diharapkan dapat menigkatkan produktivitas masyarakat dan pada akhirnya akan terjadi peningkatan pertumbuhan ekonomi. Dari pernyataan diatas maka dapat disimpulkan bahwa adanya pengaruh dana perimbangan terhadap besarnya alokasi belanja modal dan pertumbuhan ekonomi. Tujuan dari penggunaan sumber-sumber pendapatan daerah yang dialokasikan dalam belanja modal untuk pembangunan infrastruktur diharapkan dapat meningkatkan pelayanan kepada masyarakat dan dapat meningkatkan pertumbuhan ekonomi daerah.

\section{Metode}

Penelitian ini merupakan penelitian kuantitatif. Pada penelitian ini menggunakan data panel yaitu penggabungan antara data time series (runtun waktu) yaitu dari tahun 2014-2019 dan cross section (data silang) yaitu data Kabupaten/Kota di Provinsi Jambi. Jenis penelitian ini menggunakan data sekunder. Dan sumber data penelitian ini dilakukan dengan mengambil data yang diperoleh dari situs terkait antara lain yaitu: Data Dana Perimbangan dan Belanja Modal diambil dari situs Dirjen Perimbangan Keuangan Pemerintah Daerah (www.djpk.kemenkeu.go.id). Data Produk Domestik Regional Bruto Berdasarkan Atas Dasar Harga Konstan diambil dari situs Badan Pusat Statistik Provinsi Jambi (www.jambi.bps.go.id). Metode pengumpulan data yang digunakan adalah metode dokumentasi. Metode dokumentasi adalah teknik pengumpulan data yang tidak langsung pada subjek penelitian, namun melalui dokumen (Agung, 2017). Penelitian ini menggunakan path analysis melalui analisis regresi linear bertahap. Dalam menganalisis jalur dibutuhkan dua model persamaan regresi linier. Sebagai variabel independen (exogenous X) adalah Dana Perimbangan, variabel Y sebagai variabel perantara adalah Belanja Modal dan variabel Z sebagai variabel dependen (endogenous) yaitu Pertumbuhan Ekonomi. Persamaan strukturalnya sebagai berikut:

$\mathrm{Z}=\mathrm{Pzx}_{1} . \mathrm{X}_{1}+\mathrm{Pzy} . \mathrm{Y}+\mathrm{e}$

Pengujian hipotesis penelitian dilakukan dengan uji $\mathrm{F}$ dan uji t, dan sebelumnya dilakukan analisis varian (ANOVA) dengan menganalisis koefisien determinasi $\left(\mathrm{R}^{2}\right)$ untuk uji kecocokan model.

\section{Hasil}

Tabel 1

Hasil Regresi Linear Berganda Tahap I

\begin{tabular}{|c|c|c|c|c|c|c|}
\hline \multirow{2}{*}{\multicolumn{2}{|c|}{ Model }} & \multicolumn{2}{|c|}{ Unstandardized Coefficients } & \multirow{2}{*}{$\begin{array}{l}\text { Standardized Coefficients } \\
\text { Beta }\end{array}$} & \multirow[b]{2}{*}{$\mathrm{t}$} & \multirow[b]{2}{*}{ Sig. } \\
\hline & & $\mathrm{B}$ & Std. Error & & & \\
\hline \multirow[t]{2}{*}{1} & (Constant) & -57.461 & 54.409 & & -1.056 & .295 \\
\hline & $\mathrm{X}$ & .394 & .063 & .616 & 6.259 & .000 \\
\hline
\end{tabular}

Sumbe: Data Olahan

Persamaaan regresi linier berganda tahap I adalah:

$Y=-57,461+0,394 X_{1}$

Berdasarkan persamaan dari model regresi diatas dapat dijelaskan bahwa, Nilai konstanta sebesar -57,461 artinya apabila variabel independen yaitu $X$ (dana perimbangan) bernilai nol (0), maka variabel dependen belanja modal (Y) akan bernilai tetap sebesar $-57,461$. Koefisien regresi variabel $\mathrm{X}$ bernilai positif sebesar 0,394 artinya apabila variable $X$ (dana perimbangan) mengalami peningkatan sebesar satu satuan sedangkan variabel lainnya dianggap konstan, maka variabel Y (belanja modal) akan mengalami peningkatan sebesar 0,394.

Tabel 2

Hasil Regresi Linear Berganda Tahap II

\begin{tabular}{|c|c|c|c|c|c|c|}
\hline \multirow{2}{*}{\multicolumn{2}{|c|}{ Model }} & \multicolumn{2}{|c|}{ Unstandardized Coefficients } & \multirow{2}{*}{$\frac{\text { Standardized Coefficients }}{\text { Beta }}$} & \multirow[b]{2}{*}{$\mathrm{t}$} & \multirow[b]{2}{*}{ Sig. } \\
\hline & & $\mathrm{B}$ & Std. Error & & & \\
\hline \multirow[t]{3}{*}{1} & (Constant) & -8584.596 & 2682.483 & & -3.200 & .002 \\
\hline & $\mathrm{X}$ & 15.509 & 3.909 & .403 & 3.967 & .000 \\
\hline & $\mathrm{Y}$ & 27.520 & 6.110 & .457 & 4.504 & .000 \\
\hline
\end{tabular}

Sumbe: Data Olahan 
Evi Adriani et al., Pengaruh Langsung dan Tidak Langsung Dana Perimbangan Melalui Belanja Modal terhadap Pertumbuhan Ekonomi di Provinsi Jambi

Persamaaan regresi linier berganda tahap II adalah:

$Z=-8.584,596+15,509 X 1+27,520 Y$

Berdasarkan persamaan dari model regresi diatas dapat dijelaskan bahwa, Nilai konstanta sebesar $-8.584,596$ artinya apabila variabel independen yaitu X dan Y bernilai nol (0), maka variabel dependen (Z) akan bernilai tetap sebesar $-8.584,596$. Koefisien regresi variabel $\mathrm{X}$ bernilai positif sebesar 15,509 artinya apabila variabel X (dana perimbangan) mengalami peningkatan sebesar satu satuan sedangkan variabel lainnya dianggap konstan, maka variabel Z (pertumbuhan ekonomi) akan mengalami peningkatan sebesar 15,509.

Hasil uji path analisis pada penelitian ini dapat dilihat pada hasil regresi linear berganda pada Gambar 3 . Persamaan path analisis dalam penelitian ini dapat dilihat sebagai berikut:

$Z=P z x 1 . X 1+P z y . Y+e$

$Z=0,403 X 1+0,457 Y$

1. Pengaruh langsung dana perimbangan terhadap pertumbuhan ekonomi. Berdasarkan pada Gambar 3 dijelaskan bahwa, nilai signifikansi variabel $\mathrm{X}=0,000<0,05$, maka variabel $\mathrm{X}$ berpengaruh signifikan terhadap $\mathrm{Z}$, yang artinya dana perimbangan secara langsung berpengaruh signifikan terhadap pertumbuhan ekonomi.

2. Pengaruh tidak langsung dana perimbangan melalui belanja modal terhadap pertumbuhan ekonomi. Berdasarkan pada Tabel 4 dapat dijelaskan bahwa, pengaruh langsung $\mathrm{X}$ terhadap $\mathrm{Y}$ sebesar 0,616 dan pengaruh langsung $\mathrm{Y}$ terhadap $\mathrm{Z}$ sebesar 0,457 . Nilai pengaruh tidak langsung $\mathrm{X}$ melalui $\mathrm{Y}$ terhadap $\mathrm{Z}$ adalah perkalian antara nilai beta $X$ terhadap $Y$ dengan nilai beta $Y$ terhadap $Z$ yaitu : $0,616 \times 0,457=0,2815$. Maka pengaruh total yang diberikan $\mathrm{X}$ terhadap $\mathrm{Z}$ adalah pengaruh langsung ditambah dengan pengaruh tidak langsung yaitu: $0,403+$ $0,2815=0,6845$. Berdasarkan hasil perhitungan diatas diketahui bahwa nilai pengaruh langsung sebesar 0,403 dan pengaruh tidak langsung sebesar 0,2815 yang berarti bahwa nilai pengaruh tidak langsung lebih kecil dibandingkan dengan nilai pengaruh langsung $(0,2815<0,403)$. Hasil ini menunjukkan bahwa secara tidak langsung $\mathrm{X}$ melalui $\mathrm{Y}$ tidak berpengaruh signifikan terhadap $\mathrm{Z}$, yang artinya dana perimbangan secara tidak langsung tidak berpengaruh signifikan terhadap pertumbuhan ekonomi.

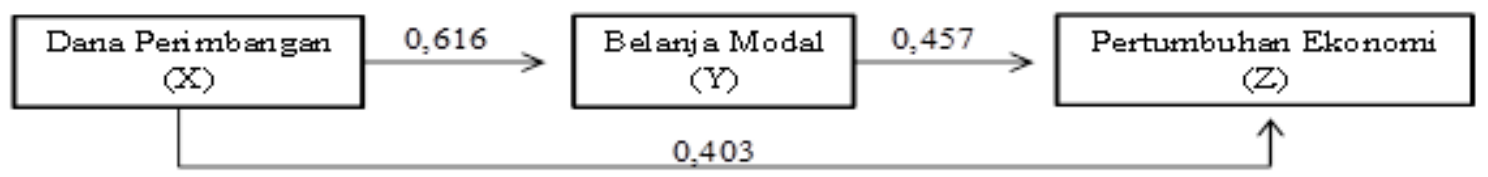

Sumber: Data Olahan

Gambar 3

Sub Struktur Jalur

Tabel 3

Nilai Koefisien Determinasi

\begin{tabular}{|l|r|r|r|r|r|}
\hline Model & \multicolumn{1}{|c|}{ R } & R Square & \multicolumn{1}{c|}{ Adjusted R Square } & Std. Error of the Estimate & Durbin-Watson \\
\hline 1 & $.773^{\mathrm{a}}$ & .598 & .585 & 4076.86813 & .667 \\
\hline
\end{tabular}

Sumbe: Data Olahan

Pengambilan keputusan perhitungan uji koefisien determinasi dapat Tabel 3. Berdasarkan tabel diatas menunjukkan nilai R Square sebesar 0,598 yang artinya bahwa besarnya kontribusi variabel dana perimbangan $(\mathrm{X})$ dan variabel belanja modal $(\mathrm{Y})$ terhadap variabel pertumbuhan ekonomi $(\mathrm{Z})$ sebesar $(0,598 \times 100=59,8 \%)$, sedangkan sisanya $(100 \%-59,8 \%=40,2 \%)$ dipengaruhi oleh variabel-variabel lain di luar penelitian ini.

Tabel 4

Hasil Uji F

\begin{tabular}{|l|l|r|r|r|r|r|}
\hline \multicolumn{2}{|c|}{ Model } & Sum of Squares & df & \multicolumn{1}{c|}{ Mean Square } & F & \multicolumn{1}{c|}{ Sig. } \\
\hline \multirow{4}{*}{1} & Regression & 1555274118.046 & 2 & 777637059.023 & 46.787 & $.000^{\mathrm{b}}$ \\
\cline { 2 - 8 } & Residual & 1047113785.077 & 63 & 16620853.731 & & \\
\cline { 2 - 8 } & Total & 2602387903.122 & 65 & & & \\
\hline
\end{tabular}

Sumbe: Data Olahan

Dengan nilai F-tabel $\alpha=0,05$ dan $\mathrm{df}(\mathrm{N}-\mathrm{K}-1)=63$ maka diperoleh nilai F-tabel sebesar 3,14. Berdasarkan tabel diatas dapat diketahui bahwa $F_{\text {hitung }}$ sebesar 46,787 dan $F_{\text {tabel }}$ sebesar 3,14. Sehingga didapatkan $F_{\text {hitung }}$ lebih besar dari $\mathrm{F}_{\text {tabel }}(46,787>3,14)$, yang artinya bahwa variabel Dana Perimbangan $(\mathrm{X})$ dan Belanja Modal (Y) secara simultan mempunyai pengaruh yang signifikan terhadap variabel Pertumbuhan Ekonomi (Z). Dengan nilai t-tabel $\alpha=0,05$ dan df $(\mathrm{N}-\mathrm{k}-1)=62$ maka diperoleh nilai t-tabel sebesar 1,998. Berdasarkan Tabel diatas hasil pengujian secara parsial dapat dijelaskan bahwa, pada koefisien regresi variabel Dana Perimbangan (X) menunjukkan bahwa t-hitung sebesar 
Evi Adriani et al., Pengaruh Langsung dan Tidak Langsung Dana Perimbangan Melalui Belanja Modal terhadap Pertumbuhan Ekonomi di Provinsi Jambi

3,967, sehingga t-hitung > t-tabel yaitu 3,967 > 1,998, maka dapat disimpulkan bahwa secara parsial variabel $\mathrm{X}$ berpengaruh signifikan terhadap variabel Z, yang artinya dana perimbangan secara parsial berpengaruh signifikan terhadap variabel $\mathrm{Z}$.

\section{Simpulan}

Berdasarkan hasil analisis data pada penelitian yang telah dilakukan, maka dapat disimpulkan bahwa:

1. Dana perimbangan secara langsung berpengaruh signifikan terhadap pertumbuhan ekonomi pada Kabupaten/Kota di Provinsi Jambi tahun 2014-2019.

2. Dana perimbangan secara tidak langsung melalui belanja modal tidak berpengaruh signifikan terhadap pertumbuhan ekonomi pada Kabupaten/Kota di Provinsi Jambi tahun 2014-2019.

\section{Daftar Pustaka}

Agung, A. A. P. (2017). Metodologi Penelitian Bisnis. UB Press. www.ipusnas.id

Amin, F. (2019). Penganggaran di Pemerintah Daerah: dalam Perspektif Teoritis, Normatif, dan Empiris. In Penganggaran di Pemerintah Daerah : dalam Perspektif Teoritis, Normatif, dan Empiris. UB Press.

Frisdiantara, C, I. M. (2018). Ekonomi Pembangunan Sebuah Kajian Teoretis dan Empiris. Deepublish. www.ipusnas.id

Peraturan Menteri Keuangan Republik Indonesia Nomor 134/PMK. 02/2012. Tentang Klasifikasi Anggaran

Sukirno, S. (2012). Makroekonomi Teori Pengantar. PT. Raja Grafindo Persada. 